\title{
Reconstruction from Models of Political Education for Beginners to Improve Political Literation: Learning from the Jambore Democracy Student Program
}

\author{
Al Rafni ${ }^{1}$, Suryanef Suryanef ${ }^{2}$, Azwar Ananda ${ }^{3}$, Nurman. $S^{4}$ \\ 1,2,3,4 Universitas Negeri Padang, Indonesia \\ *Corresponding author. Email: suryanef@fis.unp.ac.id
}

\begin{abstract}
Jamboree democracy students is one of the programs from the Commission Electoral General (KPU) Padang in educating the students to understand the election and learning democracy in general. The program is attractive because that combines the activities of Political Education with the scouting activities. This method of integration is believed to be something that is fun and gives meaning that deep for participants. This program becomes very meaningful if it is complemented by an academic study of program implementation. This article is aimed to reveal the analysis more in the implementation of the program jamboree democracy students and simultaneously reconstruct models of education policy for novice voters in increasing political literacy. Informants for this research is Commissioner KPU and Kwartir Branch of the Movement Scout Padang manager, as well as the participants of the Jamboree democracy students. The method that is used is the research and development $(R \& D)$, with the assumption that each stage can be evaluated for improvement models. The findings of this Research show that the construction of a model that is generated can overcome the problems that encountered in the field so that the implementation of the jamboree democracy students at the time to come over well and provide learning democracy are more explained to the participants.
\end{abstract}

Keywords: Political Education, Novice Voters, Democracy, Jamboree.

\section{INTRODUCTION}

Jamboree democracy students is one of the programs implemented by KPU Padang city in educating students to be able to understand elections in particular and the learning of democracy in general. This program becomes interesting because it combines political education activities with scouting activities. This program is the new strategy of KPU Kota Padang to approach voters to understand the issues of the election and become a smart voter.

Novice voters should be continuously educational given the potential for votes cast on them. In other words, a systematic and sustainable pattern of education will form good political literacy. The potential for novice voters ranges from 30 to $35 \%$ of the total number of voters. Based on data released by the Central Bureau of Statistics (2018) in the 2004 legislative elections there were 50 million more novice voters, the 2009 election reached more than 36 million, and in the 2014 election the number was 32 million more. Meanwhile, in the 2019 general election, the number of novice voters is more than 36 million.
There are several studies that reveal the importance of educating novice voters. Yoldas (2015) [1] through his research stated that political socialization and individual experience, especially as the younger generation is a complete process in which democracy is only a jargon and very little of their concern. Therefore, it is necessary to improve the political education given to this group in order to increase participation as a basic principle of democracy. Furthermore, Dinesen, et al (2016) presented in his research in three countries those are America, Denmark, and Sweden, noting that the influence of political education on people's political participation rates, especially in pre-voter children and first-time new voters. Meanwhile Rong Yu (2012) [11] through his research also proved that political education can increase the ideological level, psychological qualitie and their usefullness in developing a better career. Meanwhile, the quality of political participation which is the end point of political education is highly dependent on political knowledge (Predescu and Iona Parjan, 2011) [3]. In other words, experts believe that knowledgeable citizens are a prerequisite for the functioning of democracy. 
Therefore, this article aims to reveal how political education is implemented for novice voters through the Jamboree democracy students while constructing its model so that its future implementation is better and gives meaning to the establishment of political literacy.

\section{METHOD}

This article is part of an applied product study the authors conducted under the title Political Education Model for Novice Voters through the Students Jamboree democracy. This research uses qualitative methods. The research informant is purposively appointed as Commissioner of the Commission Electoral General (KPU) of Padang City, the teacher scout coach, the quartier Branch of Padang City Scouts, and randomly selected school messenger students who were chosen at random. Data is collected through in depth interviews, focus group discussion (FGD), and documentation studies. Data analysis is done through qualitative data analysis measures starting with data collection, data reduction, data presentation, and conclusion drawing. The validity of research data is obtained through credibility, transferability, and dependability, and can be confirmed (conformability) (Denzin, et al., 2009) [4].

\section{RESULTS AND DISCUSSIONS}

\subsection{Learn from the Jamboree democracy students program: Efforts to Improve Political Literacy.}

The student democracy Jamboree was attended by 387 participants who were representatives of the High School in Padang City. Each school sends a representative of seven students and one teacher. The findings showed that students' passion for practicing the process of electing regional heads initiated from the candidacy, the determination of candidate pairs, organizing elections on the day of the " $\mathrm{H}$ " vote, to the counting of votes and the determination of candidates for the head of the elected region. By practicing the process of organizing the selection of regional heads, students are expected to draw knowledge by learning experience to become a candidate pair, until speaking at the time of being appointed as regional head and deputy head of elected district.

The findings of the study also show that by practicing the political process directly students can understand the importance of elections themselves as well as political information that is very valuable and has a high level of accuracy. Trust in the political process is heavily influenced by one's ability to knowledge in politics. Political literacy is not a normative concept but rather a mix of knowledge, skill, and political attitudes (Bakti, 2012) [5].

According to Bernard Crick in Bakti (2010[5] political literacy is a practical understanding of the concepts drawn from daily life that is an attempt to understand the political issues, the beliefs of the contestants, how their tendencies affect themselves and others. By learning from the activities carried out through the student democracy Jamboree program, it can be stated that the participants have experienced themselves how to be a successful team on the campaign of the candidate's spouse, how to be a campaigner, how to be a supervisory committee, and how to be a polling station clerk, and other things.

Concrete experiences in the field will increase their understanding of the importance of political literacy and furthermore they will become political socialization agents for their peers, family, and surrounding neighborhoods. Departing from empirical ignition is expected program Jamboree student democracy can continue to be evaluated for the sustainability of this program in the future. According to Baltzer, Yan Ristau, and Achim Schroder (2017)[6],giving the younger generation knowledge of politics, society, judgment of a political society, allows a person to claim his rights and responsibilities in realizing a democratic society.

\subsection{Reconstruction of the Model of Political Education for Novice Voters through the Student Democracy Jamboree Program.}

In designing a model of political education it is necessary to understand what exactly the true of political education is and how political education is for novice voters. Political Education is the process of conveying information to voters to improve the knowledge, understanding, and awareness of voters about elections. As an educational effort, political education should be a systematic, comprehensive, and well-planning effort. Thus political education is not only as people talk so that students can exercise their voting rights correctly and understand the technicalities of the election. Political Education aims more than that, especially for novice voters who do not yet have preferred preferences and are easy to use by various parties. Therefore, political education must be planned in detail, systematically, and programmatically with material choices that are useful, both short-term and medium-term.

Therefore, there are several steps that must be restructuring so that planning, implementation, and evaluation can improve the sustainability of the quality of the program. The first is the issue of recruitment, in this case the recruitment of participants and the organizing committee. The recruitment of participants was improved by increasing the school's representation quota so as to have an impact on the effect of snowball for other students. Meanwhile, the recruitment of organizers should include the Education Office, local government, and journalists. Second, related to the strategy of organizing. The recommendations include: (1) the implementation of student democracy Jamboree more systematically and comprehensively in planning, 
implementation, and evaluation so as to find clear patterns from time to time; (2) in an effort to support the success of political education for novice voters, it is recommended to make this student democracy Jamboree as a programmable political education and a priority within five years; (3) the network system that enables cooperation with any party including partnering with teachers of Pancasila and Citizenship Education; (4) it needs to be intertwined with the school through the Education Office in order for the program to be more effective; and (5) for the implementation of the program is required local government involvement especially concerning the availability of facilities.

KPU Kota Padang as part of the election organizers is certainly political education obliged to carry out political education including voter's education which is allocated funds, both through state budget and state budget. Accountability for political education should be more transparent so that there needs to be supervision from local governments, especially the National Unity, Community and Political Protection (Kesbanglinmaspol) which oversees the course of political education in the region. The responsibilities and how the obstacles and sustainability should also be a concern. The clear coaching process certainly has implications on the successful implementation of the program and its sustainability. This unit periodically should not coordinate with the KPU on how effective the implementation of the program.

The implementation of political education depends heavily on the authority of the state. There are several countries that already have advanced political education such as Australia and India. In Australia there is continued cooperation from the electoral commission generally with indigenous peoples through the indigenous electoral participation program which engages civil society on an ongoing basis and becomes a means of learning citizenship politics to achieve a better democratic life. As the essence of democracy essentially teaches how different groups can argue peacefully, how to realize goals in good ways without violence and how to coexist and cooperate with all differences. In India there is also a political education program in an effort to increase voter participation through systematic voter's education and electoral participation (SVEEP) which is a systematic political education, in collaboration with civil society, educational institutions and volunteers from the young. SVEEP has a specific target audience such as women's groups, your generation, marginalized groups, and people with disabilities, as well as indigenous groups (Ravitch, 2010) [7].

Third, related to the method of political education through the Jamboree of student democracy is divided into formal and informal Formal methods consisting of: (1) seminar; (2) Focus Group Discussion (FGD); (3) socialization; (4) Lecturer; (5) workshop; and (6)
Debate. Furthermore the informal method consists of: (1) touring democracy; (2) peer group; (3) watching together; (4) arts/traditional media; (5) BRIDGE method; (6) role playing; and (7) simulations.

Fourth, related to learning materials are grouped into two important parts, namely materials concerning knowledge about elections in general and materials that support the development of voter personality, such as how to be a smart voter, motivated to excel, rational voters, and emotionally intelligent in choosing.

Improvements to the elements as previously disclosed, should be of concern to various parties involved in the implementation of the student democracy Jamboree program, especially for KPU in the Padang City. Campbell and Niemi's research (2016)[8] as well as Persson, Lindgren and Orkarsson (2016)[9]revealed the seriousness of developed countries in the implementation of political education for novice voters marked by: (1) political education management standards; (2) learning devices; (3) local government involvement; (4) cooperation network; (5) compliance with the novice selector; and (6) the ongoing evaluation system. Heller's2013research on political education for German youth through the"Under-18 Program" revealed that political education can pique the interest of teenagers in discussing election themes more interestingly. For more details on the model of political education for novice voters as well as an effort to improve its political literacy through the Jamboree of student democracy, it can be illustrated through the following image.

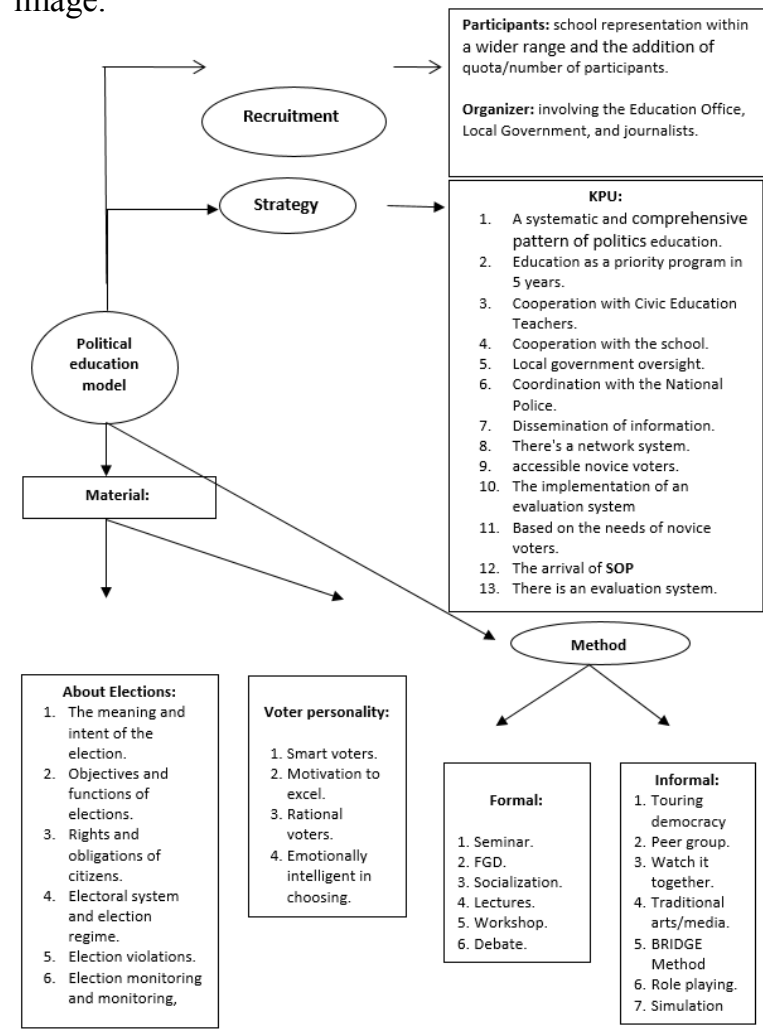

Figure.1 Political Education Model 


\section{CONCLUSION}

Political education through the Jamboree of student democracy makes participants experience the learning by doing process so as to create meaningful experiences that will continue to be inherent throughout their lives. The transformation of political education will mean more in the event of trickle-down effect to various other parties. Therefore the instructional design of political education for novice voters through the Jamboree Democracy of students that includes its strategies, materials, and learning methods is reconstructed according to the characteristics of its participants. This aims to be a fun political learning process for the younger generation as millennial.

\section{ACKNOWLEDGMENTS}

The success of completing the implementation of this research cannot be separated from the support of many parties. Therefore, thanks are conveyed to the Chancellor and Heads of the Universitas Negeri Padang in a Research and Community Service Institute for facilitating funding through PNBP Funding allocated in the DIPA of Universitas Negeri Padang through the Agreement Letter for Implementation of Leading Research for Applied Higher Education for Fiscal Year 2020 Number 1611/UN35.13/LT/2020, April 21, 2020. Thanks you for the research informants who have provided various information regarding the research data.

\section{REFERENCES}

[1] Yoldas, Ozlem Bacerik (2015). "Civic Education and Learning Democracy : Their Importance for Political Participation of Young People" dalam Elsevier, Procedia-Social and Behavior Sciencer 174, pp. 544-549.

[2] Dinesen, Peter Thisted, et-al. (2016). "Estimating the Impact of Education on Political Participation : Evidence from Monozygotic Twins in the United States, Denmark and Sweden. Polit Behav DOI 10.1007/s11109-015-9328-2

[3] Predescu, Mihai \& Ioana Parjan. (2011). "Promoting Political Participation Through Adult Education." Procedia Social and Behavioral Sciences 2 (2010) 3241-3245, doi:10.1016/j.sbspro.2010.03.495

[4] Denzin, Norman K \& Yvonna S. Lincoln. (2009). The Sage Handbook of Qualitative Research Third Edition. London : Sage Publications.

[5] Bakti, Andi Faisal. (2012). Literasi Politik dan Konsolidasi Demokrasi. Jakarta : Churia Press.
[6] Balzter, Nadine, Yan Ristau, Achim Schroder. (2017). "Political Youth Education in Germany, Presenting a Qualitative Study on its Biographycally Long Terms Effects, Journal of Social Science Education Volume 16, Number 1, Spring 2017 DOI 10.2390/jsse-v16-il-1560.

[7] Ravitch, Diane. (2010). The Death and Life of the Great American School System : How Testing and Choice are Understanding Education. New York : Basic Book.

[8] Campbell, David E. dan Richard G. Niemi. (2016). "Testing Civics : State Level Civic Education Requirement and Political Knowledge" dalam American Political Science Review Vol.110 No.3, August 2016.

[9] Persson, Mikael, Karl Oskar Lindgren dan S. Ven Orkarsson. (2016). "How Does Education Affect Adolescent : Political Development?" dalam Economics of Education Review (2016), pp. 1-37.

[10] Heler, Lydia. (2013). “"Pendidikan Politik Lewat Pemilu Untuk Remaja”, http://www.dw.com/id/pendidikan-politik;lewat pemilu-untuk remaja. Diakses tanggal 20 Oktober 2018. 